\title{
ANALISIS KARAKTERISTIK KIMIA DAN SIFAT ORGANOLEPTIK TEPUNG IKAN GABUS SEBAGAI BAHAN DASAR OLAHAN PANGAN
}

\author{
Wayan Wirawan ${ }^{1}$, Syafika Alaydrus ${ }^{1}$, Ronaldy Nobertson ${ }^{2 *}$ \\ ${ }^{1}$ Program Studi DIII Farmasi AKFAR Medika Nusantara palu \\ ${ }^{2}$ Program Studi S1 Farmasi, STIFA Pelita Mas Palu \\ *Corresponding author email : ronaldy_nobertson@yahoo.com
}

\begin{abstract}
ABSTRAK
Tepung ikan gabus yang diteliti saat ini hanya dilakukan beberapa pengujian karakteristik kimia. Masalah dalam penelitian ini apakah pembuatan tepung dari ikan gabus sebagai bahan dasar dalam pembuatan berbagai olahan dapat dilakukan, dengan tujuan untuk menghasilkan tepung ikan gabus sebagai bahan dasar olahan yang tinggi akan protein. Penelitian menggunakan rancangan analisis laboratorium, data yang dikumpul berupa data pengamatan serta pendapat panelis terhadap pendapat organoleptik. Penyajian data dalam bentuk tabel yang nantinya dianalisis sehingga diperoleh hasil apakah tepung ikan gabus sangat baik digunakan sebagai bahan olahan. Kemudian dibandingkan dengan standar yang digunakan. Hasil menunjukan bahwa pengujian karakteristik kimia tepung ikan gabus untuk kadar air yang diperoleh 10\%, kadar abu 2,94\%, kadar lemak 13,81\%, kadar serat 21,83\% dan kadar protein 65,3\%. Hasil ini sesuai dengan yang ditetapkan Food and Agriculture Organization (FAO) yang artinya tepung olahan dari ikan gabus dapat digunakan sebagai bahan olahan.
\end{abstract}

Kata Kunci: ikan gabus, karakteristik kimia, tepung

Submitted on : 8 November 2017 Accepted on: 1 January 2018

DOI: https://doi.org/10.25026/jsk.v1i9.84

\section{PENDAHULUAN}

Indonesia merupakan Negara kepulauan yang sangat luas, mempunyai kurang lebih 36.000 pulau yang besar dan kecil dengan keanekaragaman jenis flora dan fauna yang sangat banyak. Pada daerah daerah dengan perairan yang cukup luas terutama air tawar untuk pemenuhan kebutuhan kesehatan seperti untuk pengobatan tradisional [1].

obat-obat tradisional Indonesia merupakan warisan budaya bangsa sehingga perlu digali, diteliti dan dikembangkan agar dapat digunakan lebih secara efektif. Satu kenyataan yang tidak dapat dipungkiri bahwa pengobatan secara tradisional masi mendapatkan tempat dimasyarakat, pengobatan tradisional merupakan pengobatan alternatife untuk diri sendiri salah satunya adalah dengan mengkonsumsi ikan gabus untuk pasien pasca oprasi [2].

Dewasa ini hampir seluruh lapisan masyarakat mengenal berbagai produk dengan bermacam-macam kandungan nilai gizi,seperti misalnya ikan gabus. Ikan gabus kaya akan protein yang tinggi dan hanya dikonsumsi sebagai lauk pauk saja. Ikan gabus dapat dijadikan alternatif lain sebagai bahan tambahan sumber protein seperti misalnya pada pembuatan tepung pengganti bahan dasar pada pembuatan biscuit maupun olahan lain. Pada penelitian akan dilakukan pembuatan tepung dari ikan gabus sebagai bahan dasar dalam pembuatan berbagai olahan. Tujuan yang ingin dicapai dari penelitian ini adalah untuk menghasilkan tepung ikan gabus sebagai bahan dasar olahan yang tinggi akan protein [3]. 
Kegunaan dari penelitian ini adalah diharapkan menjadi bahan informasi dan sebagai bahan pembanding terhadap pengolahan ikan gabus sebagai alternatif dalam pembuatan tepung ikan gabus yang memiliki nilai kandungan protein yang sangat tinggi [4].

Data hasil pengamatan berupa analisis kandungan kimia yang terkandung dalam tepung daging ikan gabus. Yang selanjutnya akan diterapkan pada masyarakat.

\section{METODE PENELITIAN}

Pengolahan dilakukan dengan membersihkan ikan gabus, mengeluarkan semua isi perut ikan gabus dan tulangtulang yang ada pada ikan gabus tersebut, selanjutnya irisan ikan gabus dikeringkan menggunakan cabinet drier pada suhu 55$60^{\circ} \mathrm{C}$ selama 8 jam, kemudian digiling dan di ayak dengan ayakan 80 mesh.

\section{Alat dan Bahan}

Alat dan bahan yang digunakan dalam penelitian ini adalah kertas saring, kondensor, labu lemak soxhlet, labu
Kjeldahl, mortar dan satmfer, pipet tete, erlenmeyer, gelas ukur, otoklaf, tepung ikan gabus, hexane (pelarut lemak), $\mathrm{K}_{2} \mathrm{SO}, \mathrm{CuSO}_{4}, \mathrm{H}_{2} \mathrm{SO}_{4}$ pekat, aquades, $\mathrm{NaOH} 40 \%, \mathrm{H} 3 \mathrm{BO} 31 \%, \mathrm{HCl} 0,1 \mathrm{M}$, $\mathrm{H}_{2} \mathrm{SO}_{4} 0,325 \mathrm{~N}, \mathrm{NaOH} 1,25 \mathrm{~N}$

\section{Analisis Data}

Data hasil pengukuran karakteristik fisik dan kimia yang diperoleh, ditabulasi serta di analisa kemudian di jabarkan secara deskriptif.

\section{HASIL DAN PEMBAHASAN}

Pada penelitian ini dilakukan analisis kandungan kimia pada bahan/sampel yang digunakan untuk mengidentifikasi kandungan nutrisi pada suatu zat makanan dari tepung ikan gabus. Analisis kandungan kimia ini memiliki manfaat sebagai penilaian kualitas dari bahan pangan terutama pada standar zat makanan yang seharusnya terkandung didalamnya, hal ini dapat dilihat pada tabel hasil penelitian tepung ikan gabus berdasarkan karakteristik kimia

Tabel 1. Hasil penelitian tepung ikan gabus berdasarkan karakteristik kimia

\begin{tabular}{ccccccc}
\hline No & Sampel & $\begin{array}{c}\text { Kadar air } \\
\text { \% }\end{array}$ & $\begin{array}{c}\text { Kadar abu } \\
\text { \% }\end{array}$ & $\begin{array}{c}\text { Kadar lemak kasar Kadar serat kasar } \\
\text { \% }\end{array}$ & $\begin{array}{c}\text { Kadar protein } \\
\text { \% }\end{array}$ \\
\hline 1 & Ikan gabus & 10 & 2,94 & 13,81 & 21,83 & 65,3 \\
\hline
\end{tabular}

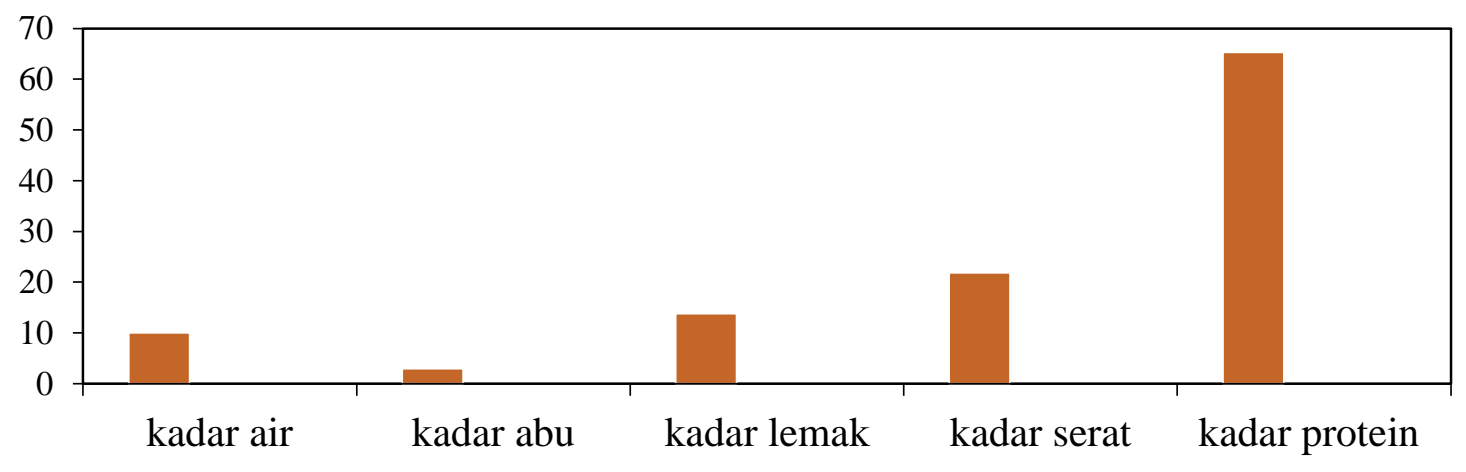

Gambar 1. Persentase karakteristik kimia 
Dilihat dari penelitian diatas pada tabel 1 Hasil penelitian tepung ikan gabus berdasarkan karakteristik kimia pada pengujian kadar air yang mana diperoleh kandungan kadar air dari tepung ikan gabus telah memenuhi standar yang ditetapkan Food and Agriculture Organization (FAO) sebesar $10 \%$ dari tepung ikan gabus itu sendiri, hal ini menunjukan tepung ikan gabus tersebut memenuhi syarat yang telah ditetapkan. Pengukuran kadar air ini bertujuan untuk meningkatkan kualitas dari produk sehingga bahan yang digunakan tetap terjaga kelembabannya, dengan demikian konsumen dalam penggunaan tepung ikan gabus ini memberikan kepuasan dalam penggunaannya.

Dilihat dari pengujian kadar abu yang telah dilakukan pada tabel 1 Hasil penelitian tepung ikan gabus berdasarkan karakteristik kimia pada pengujian kadar abu yang mana diperoleh kandungan kadar abu dari tepung ikan gabus yaitu sebesar 2,94\% tidak lebih dari 3\% hal ini dinyatakan untuk kadar abu tepung ikan gabus memenuhi standar yang ditetapkan Food and Agriculture Organization (FAO) yang menyatakan bahwa kadar abu tepung yang diolah dari bahan ikan tidak lebih dari 3\% yang mana bertujuan memisahkan bahan organik dan bahan anorganik kandungan abu suatu bahan pangan yang menggambarkan ketidak layakan suatu bahan pangan untuk dukonsumsi karena dapat menimbulkan dampak yang tidak diinginkan.

Selain kadar abu, kadar air penelitian ini juga malakukan pengujian kadar lemak yang terdapat di tepung ikan gabus, sesuai karakteristik kimia yang telah ditetapkan, dimana kadar lemak yang ditetapkan Food and Agriculture Organization (FAO) sebesar 14\% hal ini sesuai dengan hasil penelitian yang telah dilakukan terhadap tepung ikan gabus yang mana memiliki kandungan 13,81\% dilihat dari data tersebut kandungan lemak yang terkandung dalam ikan gabus sesuai yang ditetapkan oleh Food and Agriculture Organization (FAO). Penelitian ini bertujuan memberikan dampak positip serta meningkatkan derajat kesehatan terhadap kosumen yang mengkonsumsi tepung dari ikan gabus.

Tidak berbeda jauh dengan pengujian serat pada tepung ikan gabus dimana diperoleh serat yang terkandung sebasar $21,83 \%$ hal ini sesuai dengan Food and Agriculture Organization (FAO). Sebesar 22\% kesesuaian kandungan serat yang terkandung sangan pending diketahui dimana serat tersebut memiliki fungsi sebagai penurun berat badan, melancarkan pencernaan seta dapat menurunkan kolestrol dari beberapa manfaat tersebut Serat juga dapat larut sangat bagus untuk melancarkan pencernaan sekaligus membuat kolesterol dengan demikian mengkonsumsi serat juga baik untuk penyakit janutung atau penyakit kardiovaskular.

Berbeda dengan pengujian serat maupun lemak kandungan kadar protein pada ikan gabus sangat tinggi yaitu sebesar $65,3 \%$ hal ini sesuai dengan literature yang menyatakan kandungan protein ikan gabus sangat tinggi dibandingkan dengan jenis ikan yang lain selain itu dilihat dari Food and Agriculture Organization (FAO) kadar protein ikan gabus memenuhi persiaratan yang telah ditetapkan oleh Food and Agriculture Organization (FAO). Diungkapkan dalam penelitian Prof. Dr. Ir. Eddy Suprayitno, bahwa ikan gabus memiliki kandungan protein albumin tertinggi dibandingkan dengan sumber protein albumin dari ikan-ikan yang lain, seperti ikan lele, ikan bandeng, ikan mas, ikan nila, dan lain-lain. Selain itu ikan gabus juga memiliki protein tertinggi dibandingkan dengan bahan pangan yang selama ini dikenal sebagai sumber protein 
seperti telur, daging ayam, dan daging sapi. Per 100 gram, kadar protein telur hanya 12,8 gram, daging ayam 18,2 gram, daging sapi 18,8 gram sedangkan ikan gabus mencapai 25,2 gram. Sangat jauh terpautnya. Nilai plus ikan gabus yang lain ialah ikan ini memiliki nilai cerna yang sangat baik yakni mencapai

Dilihat dari data tabel 2 hasil penelitian organoleptik berdasarkan data responden dimana diperoleh hasil dari 30 responden $60 \%$ responden berusia dewasa awal dengan jenis kelamin $100 \%$ perempuan dengan status pendidikan $50 \%$ S1 hal ini disebabkan karena $100 \%$ dari responden lebih dari 90\%. Dalam penelitian ini kandungan protein yang terkandung dalam ikan gabus sangatlah penting dimana memiliki fungsi Mempercepat penyembuhan luka pasca operasi, Meningkatkan daya tahan tubuh atau berfungsi sebagai peremajaan pada sel.

merupakan ibu rumah tangga minat meningkatkan derajat kesehatan untuk keluarga sangat tinggi serta didukung pula dari status pendidikan sehingga kesadaran akan kesehatan sangatlah tinggi. Untuk lebih jelasnya dapat dilihat pada tabel 3 .

Tabel 2. hasil penelitian organoleptik berdasarkan data responden

\begin{tabular}{|c|c|c|c|c|c|c|c|c|c|c|}
\hline \multirow{2}{*}{ Responden } & \multicolumn{3}{|c|}{ Usia } & \multicolumn{2}{|c|}{$\begin{array}{c}\text { Jenis } \\
\text { kelamin }\end{array}$} & \multicolumn{3}{|c|}{ Pendidikan } & \multicolumn{2}{|c|}{ Status } \\
\hline & $\begin{array}{c}\text { Remaja } \\
\text { akhir }\end{array}$ & $\begin{array}{c}\text { Dewasa } \\
\text { awal }\end{array}$ & $\begin{array}{c}\text { Dewasa } \\
\text { akhir }\end{array}$ & $\mathrm{L}$ & $\mathrm{P}$ & $\mathrm{S} 1$ & D3 & SMA & IRT & Swasta \\
\hline 0 responden & $6,67 \%$ & $60 \%$ & $33,33 \%$ & $0 \%$ & $100 \%$ & $50 \%$ & $26,67 \%$ & $23,33 \%$ & $100 \%$ & $0 \%$ \\
\hline
\end{tabular}

Tabel 3. Hasil penelitian organoleptik berdasarkan warna tepung ikan gabus

\begin{tabular}{ccccc}
\hline \multirow{2}{*}{ Responden } & \multicolumn{4}{c}{ Skala penilaian } \\
\cline { 2 - 4 } & coklat tua cerah & coklat tua & coklat muda & coklat muda keputihan \\
\hline Dari 30(responden) & $26,67 \%$ & $66,67 \%$ & $6,66 \%$ & $0 \%$ \\
\hline
\end{tabular}

Tabel 4. hasil penelitian organoleptik berdasarkan aroma tepung ikan gabus

\begin{tabular}{ccccc}
\hline \multirow{2}{*}{ Responden } & \multicolumn{4}{c}{ Skala penilaian } \\
\cline { 2 - 5 } & sangat harum/segar & harum/Khas & Apek & sangat apek \\
\hline Dari 30(responden) & $26.67 \%$ & $70 \%$ & $6,67 \%$ & $0 \%$ \\
\hline
\end{tabular}

Tabel 5. Hasil penelitian organoleptik berdasarkan rasa tepung ikan gabus

\begin{tabular}{ccccc}
\hline \multirow{2}{*}{ Responden } & \multicolumn{4}{c}{ Skala penilaian } \\
\cline { 2 - 5 } & hambar kemanisan & hambar kenyal & kemanis-manisan & kenyal \\
\hline Dari 30(responden) & $33,33 \%$ & $66,67 \%$ & $0 \%$ & $0 \%$ \\
\hline
\end{tabular}

Tabel 6. Hasil penelitian organoleptik berdasarkan tekstur tepung ikan gabus

\begin{tabular}{ccccc}
\hline \multirow{2}{*}{ Responden } & \multicolumn{4}{c}{ Skala penilaian } \\
\cline { 2 - 5 } & Kering & Lembab & Agak menggumpal & Sangat menggumpal \\
\hline Dari 30(responden) & $93,33 \%$ & $6,67 \%$ & $0 \%$ & $0 \%$ \\
\hline
\end{tabular}


Dilihat dari tabel 3 hasil penelitian organoleptik berdasarkan warna tepung ikan gabus dimana responden/panalis sekitar $66,67 \%$ menjawab coklat tua, $26,67 \%$ coklat tua cerah dan $6,66 \%$ menjawab coklat muda, hal ini mungkin dipengaruhi dari factor warna daging ikan gabus yang memiliki warna yang coklat, sehinga kebanyakan responden memberikan jawaban warna coklat.

Dilihat dari tabel 4. hasil penelitian organoleptik berdasarkan aroma tepung ikan gabus dimana responden/panalis sekitar $70 \%$ menjawab harum/khas, 26,67\% sangat harum/segar dan $6,67 \%$ menjawab apek, hal ini mungkin dipengaruhi dari faktor bau khas dari ikan gabus yang memiliki bau menjolok, sehinga kebanyakan responden memberikan jawaban harum yang khas

Dilihat dari tabel 5. hasil penelitian organoleptik berdasarkan rasa tepung ikan gabus dimana responden/panalis sekitar 66,67\% menjawab hambar/kenyal, dan 33,33\% hambar kemanisan, hal ini mungkin dipengaruhi dari faktor ikannya yang khas dimana memiliki protein yang tinggi, sehinga kebanyakan responden memberikan jawaban hambar dan kenyal.

Dilihat dari tabel 6 . hasil penelitian organoleptik berdasarkan tekstur tepung ikan gabus dimana responden/panalis sekitar 93,33\% menjawab teksturnya kering, dan 6,67\% menjawab teksturnya lembab, dilihat dari hasil yang diperoleh hal ini mungkin disebabkan dari factor kandungan kadar air dari ikannya dimana memiliki kandungan air yang sangat rendah, sehinga kebanyakan responden memberikan jawaban teksturnya kering.

\section{KESIMPULAN}

Ikan gabus sangat baik digunakan sebagai bahan dasar olahan tepung di mana memiliki kandungan kadar air 2,94\%, kadar lemak 13,81\%, kadar serat 21,83 dan protein $65 \%$ sesuai dengan standar Food and Agriculture Organization (FAO) yang memiliki manfaat sangat tinggi bagi tubuh.

\section{DAFTAR PUSTAKA}

[1]. Retno, IT.2007. Buku Pegangan Ilmu Pengetahuan Kosmetik. PT. Elexa Pustaka: Jakarta.

[2]. Wibisono, Y. 2009. Metode Statistika. Gadjah Mada University Press: Yogyakarta.

[3]. Hardjono. 2005. Spektroskopi. Universitas Gadjah Mada: Yogyakarta.

[4]. Arikunto, S. 2006. Prosedur Penelitian Suatu Pendekatan Praktik. Edisi Revisi VI. PT. Rineka Cipta: Jakarta

[5]. Ansel, C.H. 1989. Pengantar Bentuk Sediaan Farmasi Terjemahan Farida Ibrahim Edisi IV. Universitas Indonesia Press: Jakarta. 496, 515, 523.

[6]. Kartodidjojo, S. 1988. Pedoman Pengujian Sediaan Rias. Pusat Pemeriksaan Obat dan Makanan Direktorat Jenderal Pengawasan Obat dan Makanan. Departemen Kesehatan Republik Indonesia: Jakarta. 17

[7]. Balsam, M.S. 1972. Cosmetic Science and Technology Second. Edition Vol 1. Wiley Intersience; New York. 55, 450, 510.

[8]. Adhi, J. 2002. Ilmu Penyakit Kulit dan Kelamin. Edisi III. Fakultas Kedokteran Universitas Indonesia: Jakarta 